\title{
LA CURIOSIDAD DE LAS PALABRAS Y LA SENDA DEL CORAZÓN EN MUJERES INDÍGENAS DE GUATEMALA ${ }^{1}$
}

\author{
JULIÁN LÓPEZ GARCÍA ${ }^{2}$ \\ Universidad Nacional de Educación a Distancia
}

Resumen: Este texto trata de la socialización de mujeres indígenas guatemaltecas enfocada a dos aspectos: cómo deben comportarse en relación a la vida pública y cómo deben orientar sus sentimientos. Se destaca que la formalidad en la educación moral de las mujeres contrasta con su vida social. Finalmente se sugiere la conveniencia de considerar en planos de igualdad tanto las narrativas formales como práctica social.

Palabras Clave: mujer indígena, Guatemala, huehuehtlatoli, socialización.

Aвstract: This text is about the socialization of indigenous Guatemalan women, focusing on two aspects: how they should behave in relation to public life and how they should direct their feelings. We highlight the idea that the formality of women's moral education contrasts with their social life. Finally, the text suggests the desirability of considering both formal narratives and social practice on an equal basis.

KeYwords: indigenous women, Guatemala, huehuehtlatoli, socialization.

Sin haber leído los libros de los filósofos clásicos, los indios de América criaban general y naturalmente a sus hijos siguiendo las doctrinas de estos filósofos. Con esa contundencia lo afirmaba Mendieta en el capítulo XX de su Historia eclesiástica indiana (De cómo estos indios general y naturalmente criaban á sus hijos en la niñez, siguiendo las doctrinas de los filósofos, sin haber leido sus libros).

${ }^{1}$ Este texto se ha elaborado en el marco del Proyecto de Investigación I+D+i del Ministerio de Ciencia y Tecnología «Los pueblos indígenas y la modernidad en América Latina» (HAR 2011-25988).

2 jlopezg@fsof.uned.es 
Mendieta, en cualquier caso, no era original en ese capítulo. Estos consejos con los que los padres educarían a sus hijos (buebuetlatolli en lengua nahua) procederían del verdadero recolector, el Padre Fray Andrés Olmos, de quien la tomarían todos los demás primeros cronistas que después los utilizaron: Torquemada (en Monarquía Indiana) Las Casas (en la Apologética Historia Sumaria), Zorita (en la Relación de Nueva España) y el propio Mendieta, cuyas palabras fueron claras al respecto: Olmos sería «la fuente de donde todos los arroyos de esta materia emanan.... ${ }^{3}$. No conocemos lo que originalmente redactó Olmos en el inicial Tratado de las antigüedades mexicanas ni en la posterior Suma, pero no debería variar mucho de lo que los otros difundieron.

Como ha señalado Baudot los huhuehtlatoli tendrían un doble valor y significado, literalmente es «discurso de los ancianos» $\mathrm{o}$ «discurso antiguo» y designa un verdadero género literario compuesto de arengas, preceptos y consejos morales... en cierto modo parece una retórica moral que, además de una meta educativa evidente, permite dar rienda suelta al refinado arte del bien decir que los antiguos mexicanos tenían en gran estima» (1983: 238). Para García Quintana la acepción correcta sería «antigua palabra» (1974: 138).

Tomando a Mendieta vemos que, entre otros asuntos, las recomendaciones de los padres a sus hijas hacían referencia a la evitación de la pereza y la defensa del bien de la diligencia en la casa: «no seas descuidada ni perezosa; pero serás diligente y limpia y muy concertada en tu casa»; a la honestidad en el andar y el mirar: «... por donde quiera que fueres ve con mucha mesura y honestidad, no apresurada ni riendo ni mirando de lado, como a medio ojo, ni mires de hito a los que vienen de frente, ni a otro alguno no le mires de lleno en la cara, pero irás en tu camino derecho, mayormente si fueras acompañada...», a la contención del sueño y el descanso: «...guárdate también de darte demasiadamente al sueño, a la cama y a la pereza... No sigas la sombra, el frescor ni el descanso, que todo eso te acarreará malas costumbres y el mucho regalo enseña pereza y vicio y con este mal ejemplo no se puede vivir bien ni ser agradables las mujeres»; a la conveniencia de desdeñar las llamadas del corazón y evitar el sexo y el vicio: «no te des a cosas malas y huye de la fornicación; no sigas tu corazón porque te harás viciosa; te engañarás y ensuciarás a ti misma y nos afrentarás a nosotros; no te envuelvas en maldades como se envuelve y enturbia el agua»; a la conveniencia de evitar la calle y el mercado y las mundanas compañeras femeninas: «mira, hija, que

3 Una revisión exhaustiva de la obra de Olmos y el papel de los huehuetlatolli en la misma se puede ver en Baudot, 1983 (167-245). 
no tomes por compañeras a las mentirosas, a las malas mujeres, a las callejeras, cantoneras, ni perezosas, porque no te descompongan ni perviertan; mas solo debes entender en lo que conviene a nuestra casa, ni salgas fácilmente fuera de ella, ni andes por el mercado, por la plaza y baños, ni sola por los caminos, que todo esto es muy malo por estar allí el daño y perdición, y el vicio saca de seso y desatina más que las hierbas ponzoñosas»; a la prohibición de la conversación con hombres en la calle: "Si por el Camino, ó Calle, por donde fueres, encontrares con algún moço atrevido, y se te riere, no te rías con él; pero calla, y pasa, no haciendo caso de lo que te dijere, ni pienses en sus palabras, ni las estimes en nada. Si te siguiere, diciendo algo, no le buelvas la cara, ni le respondas, porque no le muevas más el coraçon al deshonesto»; y, en fin, la advertencia sobre el peligro de visitas a otras casas: "No entres (Hija mia) sin propósito, y sin ocasión en casa de otro, porque no te levanten algún falso testimonio; pero si entras en casa de tus parientes, ó deudos, tenles acatamiento, y hazles reverencia, y no estés ociosa en su presencia; pero toma luego el huso, y hila y texe, ó ayuda, en lo que vieres, que conviene hacer, según lo que hicieren, y en ninguna manera estarás mano sobre mano... ${ }^{4}$.

Hubo otro recopilador primario de huehutlatolli, Fray Bernardino de Sahagún, que los habría obtenido entre 1547 y 1558, unos 20 años más tarde y con distinta procedencia a los de Olmos. Algunas notas de esas exhortaciones en el texto de Sahagún se refieren a la contención y honestidad en los vestidos: «Mira que tus vestidos sean honestos y como conviene; mira que no te atavíes con cosas curiosas y muy labradas, porque esto significa fatassaría y poco seso y locura...»; a la necesidad del sosiego y la evitación de la curiosidad y desmesura en la palabra: «cuando hables no te apresurarás en el hablar, no con desasosiego sino poco a poco y asosegadamente. Cuando hables no alzarás la voz ni hablarás muy baxo sino con medio sonido. No adelgazarás mucho tu voz cuando hablares o cuando saludares, ni hablarás por las narices, sino que tus palabras sean honestas y de buen sonido y la voz mediana; no seas curiosa en tus palabras...»; a discreción y honestidad en el andar, saltar y mirar: «en el andar has de ser honesta; no andes con apresuramiento ni con demasiado espacio, porque es señal de pompa andar despacio, y el andar deprisa tiene resabio de desasosiego y poco asiento. Andando llevarás un medio, que ni andes muy deprisa ni muy despacio, y cuando fuere necesario andar deprisa, hazerlo has así; por esso tienes discreción. Para cuando fuere menester saltar algún arroyo, saltarás honestamente de manera que ni parezcas pesada y torpe, ni liviana... Cuando fueres por la calle o por el camino

\footnotetext{
4 Todas las citas de la edición de 2012 pp. 118-119.
} 
no lleves inclinada la cabeça y muy erguida, porque es señal de mala crianza. Irás derecha y la cabeça poco inclinada. No lleves la boca cubierta o la cara con vergüenza; no vayas mirando a manera de cegajosa; no hagas con los pies meneos de fantasía por el camino; anda con sosiego y con honestidad por la calle...cuando fueres por la calle, no vayas mirando acá ni acullá, ni volviendo la cabeça a mirar a una parte y a otra; ni irás mirando al cielo ni tampoco irás mirando a la tierra...»; a la conveniencia de no reparar en palabras de la calle, «no te des nada por las palabras que oyeres yendo por el camino, ni hagas cuenta de ellas, digan lo que dixeren los que van o vienen. No cures de responder ni cures de hablar, mas haze como que no lo oyes ni lo entiendes, porque haziendo de esta manera nadie podrá decir con verdad: dixiste tal o tal cosa» ${ }^{5}$.

En fin, unos apuntes más de Motolinía en su Historia de los indios de la Nueva España donde destaca cómo esas exhortaciones acababan teniendo trascendencia social pues determinaban los comportamientos femeninos: «la vida de la mujer es criarse, estar y vivir en la cocina» y así, «siendo niñas de cinco años las comenzaban a enseńar a hilar, tejer, y labrar y no las dejaban andar ociosas, a la que se levantaba de la labor fuera de tiempo, le ataban los pies, para que se sentara y se estuviera quieta, las hacían velar, trabajar, madrugar... las tenían tan recogidas y ocupadas en sus labores que casi nunca salían y si algunas veces era necesario que saliesen entonces lo hacían con mucha y grave compañía»; «iban tan serias que no alzaban los ojos del suelo, y si se descuidaban, luego les hacían la señal que recogiesen la vista y si no obedecían con muy ásperas ortigas les castigaban las carnes cruelmente, las pellizcaban hasta que las dejaban llenas de cardenales» ${ }^{6}$.

Y una última referencia sobre la sumisión femenina a los hombres. Miguel León Portilla, en la moderna traducción que hace de uno de los huehuetlatolli recogidos por Fray Bernardino de Sahagún, relata así una de las recomendaciones del padre a su hija respecto a la obediencia necesaria al esposo hasta la muerte: «quien quiera que sea tu compañero, vosotros juntos, tendréis que acabar la vida. No lo dejes, agárrate de él, cuélgate de él, aunque sea un pobre hombre, aunque sea solo una aguililla, un tigrito, un infeliz soldado, un pobre noble, tal vez cansado, falto de bienes, no por eso lo desprecies» (1961: 341).

La validación y continuidad de estas exhortaciones quedó patente en referencias históricas y etnográficas que ampliaban la presencia y vigencia a lo largo de

5 Todas las citas textuales proceden de la edición de Juan Carlos Temprano de 2001, pp. 498-501.

6 Todas las citas de Motolinía proceden de la edición de O’Gorman de 1971, pp. 425-26. 
toda Mesoamérica. A mediados del s. XIX García Elgueta, en su estudio sobre el departamento guatemalteco de Totonicapán, volvía a reparar en estos mismos principios morales señalados por los cronistas, sugiriendo que eran patrimonio no de nahuas mexicanos sino de la nación maya-quiché guatemalteca y considerando que «las gentes que practicaban semejante moral y costumbres de urbanidad y los padres que inspiraban a sus hijos tales enseñanzas, no pueden menos que haber sido sociedades cultas, cuyas puras doctrinas de paz, de amor, de caridad y de respeto social, casi eran un trasunto de las doctrinas de Solón y de Jesucristo y de otros grandes moralistas de la antigüedad» (1962: 149).

La importancia social y moral de los consejos en la actualidad ha sido reconocida por Pedro Pitarch entre los tzeltales de Chiapas. Ha referido que los consejos que dan los padres a los hijos (llamados mantanil) prestan una atención preferente a las cuestiones de corrección corporal y de etiqueta social, especialmente en cuanto a la demostración de respeto a parientes y vecinos (2001: 131). Uno de sus informantes, Miguel Gómez, decía: «Entonces, cuando eres padre, le das mantal a los hijos, en el mantal tienes que dar una sagrada palabra, buenas palabras para que tus hijos comprendan... los niños deben seguir el ch'ul be mantal, el sagrado camino de los consejos» (ibíd.: 132-133).

Básicamente las recomendaciones de esta pedagogía moral sobre las mujeres indígenas focalizaban su atención en la conveniencia de contener tanto la libertad de movimientos del cuerpo (primero respecto a la potencia proyectiva de sus órganos sensoriales opacando vista, voz y oído y, segundo, en relación a la libertad performativa de otros órganos que tienen poder creativo: piernas que generan tipos de pasos, manos que se mueven de una u otra forma, rostros cambiantes en función del gesto) como la libertad que dicta el sentimiento. En el fondo se trataría de modular dos de las principales vías de expansión nacidas de la intimidad femenina: la curiosidad de las palabras y las llamadas del corazón.

Trato en este texto sobre la enseñanza moral orientada hacia las mujeres indígenas guatemaltecas, aunque se podría decir también que mesoamericanas. Particularmente hablo de cómo los valores de las narrativas pedagógicas difieren de las prácticas sociales. Me centraré básicamente en las presencias discursivas, en el relato pedagógico, relativas a los usos correctos que la mujer debe dar a los deseos de sus palabras y a los de su corazón, y también trataré sobre cómo congenian estos relatos con las prácticas sociales. El asunto provoca, finalmente, una reflexión acerca de la tendencia pendular de la Antropología Social que, unas veces fascinada por el relato, construye teoría basándose exclusivamente 
en él y otras, seducida por los sentidos, desdeña el relato, desconsiderando la coexistencia de ambas aproximaciones a la hora de sugerir cómo es la vida social.

\section{La senda correcta del corazón y de las palabras femeninas. Actualidad de las antiguas enseñanzas morales}

De alguna manera, en todas las exhortaciones y consejos morales indígenas que conocemos a través de los cronistas hay un acuerdo generalizado sobre la conveniencia de fomentar la reclusión femenina en la casa con el doble objetivo de impedir que sus palabras construyan, orienten o revoquen el orden social fuera de la domesticidad e, igualmente, que el sentimiento nacido del corazón sea el que dicte las convergencias sociales, particularmente amorosas. En definitiva, abortar la curiosidad de las palabras, entendiendo por tal impedir su capacidad genésica, y desalentar la llamada del corazón, restando autonomía a la sentimentalidad femenina.

Mucho se alegrarían aquellos cronistas de encontrar hoy relatos en los que las recomendaciones siguen teniendo, cuatrocientos años después, cierta vigencia y continúan siendo base de cierto orden moral y social.

En la actualidad seguimos encontrando en muchas etnografías referidas a indígenas mayas abundantes referencias acerca de los preceptos morales que los padres transmiten a sus hijas. Unos preceptos que habrían tenido claras consecuencias sociales y que harían convergente el papel de las mujeres indígenas con el de muchas mujeres en otros lugares del mundo.

En los años sesenta del siglo pasado la antropóloga norteamericana Susan Tax (1980) escribía un texto sobre las actividades domésticas de las mujeres mayas de Zinacantán, Chiapas, México. Hablaba de las connotaciones peligrosas de la ociosidad y entendía que el énfasis en el valor otorgado en esa comunidad al trabajo doméstico femenino era el resultado, en buena medida, de un valor de desplazamiento ideológico. Concretamente viene a decir que existe una presión en Zinacantán para que las mujeres empleen toda su energía y todo su tiempo en el trabajo doméstico, aunque éste no sea productivo, porque no hacerlo así podría ser moralmente reprobable y socialmente peligroso; lo sería porque el correlato de la ociosidad se desplaza hacia la amoralidad. Atendiendo los consejos de los padres se convertirá en una mujer trabajadora y responsable, una mujer p’ih. Ésta no sólo hace muchas y buenas tortillas de maíz diariamente, trae leña y 
agua, teje, lava y compone ropa, sino que aun habiendo terminado de realizar las tareas domésticas necesarias continúa trajinando en la casa porque la ociosidad femenina es sentida como una amenaza y, por tanto, resulta peligrosa, sinónimo de degradación moral y de disolución social. Una mujer perezosa e irresponsable es una mujer chah, aquella que, según el estereotipo, se sienta habitualmente con otras mujeres, chismea y participa en grupos corporados. Según Tax el marido de una mujer ch'ah se halla triste porque entiende que su matrimonio es un fracaso.

En la tesis de Tax el desplazamiento de la energía hacía el trabajo y el entrenamiento de la laboriosidad y la responsabilidad doméstica tienen que ver con el temor de los hombres a la naturaleza sexualmente agresiva de las mujeres. Por eso se evita la ociosidad y se impediría la participación de las mujeres en asuntos fuera del hogar. Esa es la razón por la que una mujer trabaja en la casa no sólo para responder a las necesidades explícitas «de la casa», sino para probar que no ha podido hacer nada más, que equivale a decir nada malo. Así una mujer, una esposa, «que trabaja bien» no es únicamente la buena ama de casa sino la esposa digna de confianza que no ocasionará sospechas ni maldades. La ociosidad sería una manifestación clara de irresponsabilidad femenina, sobre todo por sus consecuencias morales. Por eso debe ser evitada y por eso se impediría la participación femenina en el exterior, por el miedo instalado culturalmente a que el poder masculino se vea menoscabado, aunque se ponga énfasis en el miedo a la disyunción familiar. Así se presiona a la mujer a trabajar mucho y a trabajar dentro; a no salir para no dar rienda suelta a la curiosidad de las palabras ni a la libertad del corazón.

Una mujer $p^{\prime} i h$ debe quedarse en casa. Su compromiso debe ser estrictamente doméstico. La casa es el ámbito donde se concreta la responsabilidad femenina de «dar vida»: tener listas para la familia buenas y suficientes tortillas, moler, tejer, lavar, educar a los niños y alimentarlos, llevar almuerzo a la milpa y regresar rápidamente, buscar agua y leńa... pero siempre regresar rápidamente. Si la educación recibida por las mujeres es adecuada y su comportamiento correcto, lo esperable es convertirse en una mujer $p$ ih

Lucía Willis Paau, una activista cultural maya-queqchi, recordaba hace unos años su educación en esa misma línea que impedía la proyección de sus palabras y de su corazón:

«Desde adolescente me enseñaron mi papel como mujer, tener las responsabilidades de la casa y del cuidado de los animales, los cultivos, lavar, 
cocinar y además tener una mística para hacerlo, tener un lenguaje propio de trato y sabiduría para hacer bien las cosas ya que de lo contrario daba mala imagen como mujer.

Mi mamá me aconsejaba no tener amistades y no jugar con los varones porque ellos son agresivos, bruscos y además me podían hacer algo malo. Yo crecí en un ambiente sano ya que en forma de juego hacíamos algunas tareas como cortar café, pacaya, frijoles y otras clases de cultivo. Yo tuve más apoyo de mi madre pues ella nos educó, la obedecíamos y siempre la he tomado como ejemplo. También contábamos con la educación del abuelo quien nos infundía la formación ética, moral y espiritual.

En la educación moral, mi abuelo nos decía a las dos mujercitas que al pasar enfrente del hombre que esté sentado, teníamos que recoger nuestro corte con cuidado para no quitarle el poder, ya que si una mujer pasa y roza su corte con el hombre este se queda tonto. Si rozábamos nos regañaban. Y así nos aconsejaba sucesivamente sobre las cosas del varón; no podíamos pasar encima y cuidado si pasábamos sobre sus pies si él los tenía estirados y si esto ocurría la castigaban a una drásticamente. Al hombre no se le podía dar el resto de la comida sino servirle a él primero y si él no había llegado no se podía tocar la comida hasta que él llegara. Recuerdo cómo nos decían que nosotros los niños y las mujeres no podíamos comer de la comida hasta servirle al que trabajara, tenemos que esperar o comer otras comidas que haya. Al servir al hombre se le da lo mejor mientras que a la mujer se le da lo que sobra.

En la etapa de la juventud mi preparación fue mucho más fuerte. Primero me aconsejaron muy especialmente sobre la dignidad como mujer, cuidándola y conservándola para toda la vida ya que es lo más valioso que una mujer puede tener, por lo tanto se debe de llevar siempre presente y en alto sin mancharla... Cuidado de no juntarnos con un joven ladino porque son vanidosos, oportunistas e irrespetuosos con nosotras las mujeres indígenas. Me aconsejaban no salir de la casa.

No se si estos consejos me infundieron mucho miedo, pero me influyeron mucho ya que tenía miedo a cualquier joven que se me acercaba, tenía el temor de que podría hacerme daño. Esto contribuyó a que yo, y todas las mujeres que yo conocía, fuéramos miedosas, tímidas y sumisas; recuerdo que no me ayudaron a tener autoestima porque nos decían que nosotras las muje- 
res no servíamos de nada, que el varón era de gran valor y por lo tanto se le debe servir, atender lo mejor que uno pueda y también se le quería mucho más que a nosotras las mujeres, se les decía que ellos eran los jefes de la casa, lo que ellos nos dijeran nosotras debíamos obedecer...» (2000: 76-78).

Yo mismo he anotado algo similar respecto a la mujer maya-ch'orti'. Los pilares centrales en la educación de la mujer indígena ch'orti' se concretan en la necesidad de no ser haragana en los trabajos asignados y en ser "dura» ante las propuesta masculinas de convergencia emocional y sexual antes del emparejamiento formal. Respecto a este asunto una de mis informantes, dońa Margarita García, me decía: «La mujer tiene que hacerse dura, si es blandita eso es lo que quieren los hombres, porque los hombres es igual a los perros, porque los perros olfatean una chucha y si la miran que ya está echando el olor, se amontonan todos...» Una muchacha que actúa de manera congruente con las enseñanzas de sus padres es aquella que se hace «la dura», no da confianza y somete su apertura sexual al beneplácito de la relación formal aprobada por los padres. De esta manera ella no es responsable directa y única de su devenir sino que delega, o al menos comparte, la responsabilidad con sus padres, pues tiene a bien dejarse llevar por las consideraciones de éstos y no por las llamadas de su corazón. Podríamos decir que formalmente la llave de su corazón y la llave de su vagina la tienen sus padres. En cambio si se va con un muchacho sin acuerdo de los progenitores, si sigue las llamadas del corazón, se convierte en la única responsable de su devenir: "Pueden salir a escondidas si es su gusto con el muchacho, pero si se va a escondidas si [al cabo del tiempo] la está golpeando [el muchacho], si la está macheteando la cabeza... es su gusto [el causante], como no quiso estar sola... aparte sería que hubieran recibido la dona [la aceptación formal de los padres]... pero como a su gusto fue a hallar al muchacho, si le están pegando, que le peguen... ya no es responsable ninguna gente... es igual a una chumpa [pava] que a lo mejor se fue a hallar jolote [pavo]... ¿vino o no vino?... ¿quién es responsable?... otra cosa es si el papá recibió la dona, si la están golpeando a la hija tiene que ir a ver... si es vergueador el muchacho, si la están jodiendo tiene que ir a ver y decir: "¡no pegués a la muchacha, que no es en la calle donde la hallaste!», en casa la vino a buscar... siempre hay remedio, y el que se va a escondidas no hay remedio». Es decir, la invitación pedagógica a la obediencia y a la represión femenina tendría una justificación social: la necesidad de seguridad. La mujer que se deja llevar por su corazón pierde seguridad, ese es el mensaje primario de la enseñanza moral. 
A la hora de buscar continuidades, ¿cómo no recordar nuevamente los huehuetlatolli?, por ejemplo la versión de Fray Bartolomé de las Casas en el Capítulo CCXXIV del libro tercero de la Apologética: «si tomares en tus entrañas esto que te he dicho y avisos que te he dado, vivirás alegre y consolada; pero si no lo recibieres poniéndolo por obra, será tuya la culpa y padecerás tu desventura y adelante verás lo que te sucederá por no tomar los consejos de tu madre y por echar atrás lo que te conviene para bien vivir; no más, hija» ${ }^{7}$.

Pero junto a este discurso que alude a las desgraciadas consecuencias que la apertura tendría sobre la seguridad femenina, habría otro relato justificativo de esa moral de la contención que habla, como sugería Susan Tax, del miedo masculino a la apertura femenina. Aunque no se exprese en la retórica de los consejos, encontramos claramente una conexión con el miedo masculino a ser dominado por parte de una mujer autónoma en su sentimentalidad y sexualmente abierta.

El mensaje moral que va en los consejos -que son «palabra antigua»- se articula con otras palabras antiguas transmitidas en forma de mitos que vienen a ser, en muchos casos, ejemplos de las consecuencias que se derivarían de seguir, o no, los consejos de padres o de los mayores en general. Por ejemplo, con relación a la conveniencia de contener el cuerpo y no abrirlo mucho tenemos en toda la región una pléyade de mitos que hablan de mujeres excesivamente abiertas que atemorizan, dañan y provocan rupturas en los ámbitos familiar y comunitario e inversiones en la detentación del poder.

El ejemplo de la Ciguanaba es claro. Se trata de una de las apariciones más extendidas en toda Mesoamérica. Según Gustavo Correa (955: 74) sería un personaje que recordaría el perfil de una antigua diosa en forma de serpiente que vive bajo las cuevas esperando la captura de hombres para llevarlos al ultramundo o arrojarlos al cenote. Generalmente engaña, apareciéndose en forma de bella mujer y conduciendo a los «espantados» hacia lugares desconocidos.

Baez-Jorge lleva tiempo estudiando la mitología de la vagina dentada en Mesoamérica. Por ejemplo dice respecto a su presencia en la mitología zoque:

«En el chichonal vive Piowačwe, una mujer encantada que quería casarse con Tumšawi. Él la espiaba cuando se bañaba, tenía escamas. En el día

7 La cita de la edición digital de la Fundación del Libro Total, http://www.ellibrototal.com/ p. 3711 . 
era joven, en la tarde era recia y en la noche vieja y fea. Tenía dientes en su cosa de mujer [vagina $=t u k]$. Tumśawi tenía miedo del abrazo [copulación = hupaba] y Piowačwe se enojó. Tembló y regó el agua de la laguna donde estaba, se fue al volcán Tanaca [en Guatemala] y luego regresó acá a su tierra. Cuando llega es cuando tiembla, por enero o mayo, y echa humo porque se está quemando.

Piowačwe mantiene claras afinidades simbólicas con Nawayomo (la mujer mala o de agua "con vagina dentada»), a la que se atribuye la seducción de hombres a los cuales castra en la cópula» (2000: 342-343).

El temor a la castración por la vagina dentada es frecuente en la mitología. El mito huichol de Kauyumari refiere cómo este héroe puso dientes en las vaginas de las mujeres para impedir que la raza humana creciese mucho. Después olvidó lo que había hecho y él mismo tuvo relaciones sexuales con una mujer y resultó


información sobre Nawayomo y la describe como una serpiente monstruosa que se transformaría en mujer para seducir a los hombres y cuya vagina es la boca de una culebra:

«Hay una culebra en los arroyos, es grande como mazacoate. Es la culebra que se vuelve Nawayomo (...) es mujer pero su cosa [órgano genital] es la boca de una culebra; los muchachos no saben y la siguen. Por eso se mueren de hemorragia, porque los muerde cuando la usan [copulan]; salen en las noches» (Báez-Jorge 1990:10) ${ }^{9}$.

Las mujeres con una serpiente en la vagina también están presentes en un relato mixteco de Oaxaca según el cual un hombre se enamoró perdidamente de una mujer, pero después de haber copulado con ella descubrió, horrorizado, que su vagina era la boca de una serpiente. Poco después murió (Monaghan 1995: 145).

Oswaldo Chinchilla (2010) ha estudiado la conexión entre estas mujeres sexualmente agresivas con otros personajes que aparecen en fuentes arqueológicas y etnohistóricas prehispánicas. Las serpientes dentadas en la vagina de estas mujeres se vincularían con las fauces ventrales de los pájaros en Izapa, con héroes

${ }^{8}$ Otros mitos sobre la vagina dentada los podemos encontrar en Galinier (1984) y Lupo (2002).

9 Se puede complementar en Baez-Jorge (2008a y 2008b). 
o dioses que se caracterizan por su cojera o por la amputación de algún miembro y, en fin, con el personaje del Popol Vuh Siete Guacamayo, personajes todos transgresores y muy abiertos sexualmente.

Sin duda hay una convergencia de sentido con el pasado, pero todavía podemos encontrar una convergencia más llamativa que nos advierte de la tremenda capacidad aditiva de las culturas indígenas mesoamericanas. La identificación entre la serpiente y la apertura sexual, clara en la mitología prehispánica y colonial, permite que sea inteligible un relato actual como es el mito ch'orti' (y de otros contextos etnográficos) de Adán y Eva. La pareja cerrada y sin aberturas inicialmente vivía supuestamente de manera ideal en un tiempo pasado hasta que la serpiente abrió sexualmente a Eva y ésta a Adán. Una de las versiones del mito ch'orti' de la génesis de la nueva humanidad a partir de Adán y Eva me fue narrada por D. Nito en Tunucó Abajo:

«Adán dicen que era crianza de Dios. Pasó que el Señor lo mandó de cuidar una finca; se mantenía de la fuerza de Dios y el Señor le dijo que de un árbol no pueden tentar la fruta porque se pierden. Y ahí estaba el hombre y cuando pasaba la Eva y le dijo "¿querés esta fruta?», «no, porque me pierdo»; «comé, si comés esta fruta te despertás»; dijo la sirpienta ${ }^{10}$ : «no te morís, más te despertás»; «me dijo mi Padre que no, que me pierdo...»; «mentira». Lo enseńó a Adán, [lo comió], «sabroso», dijo... la Eva [en aquel tiempo] no tenía chuchito [vagina] como decimos a las mujeres, era limpio y Adán lo mismo no tenía frutillo [pene] y ella lo llevó la fruta a la boca de Adán y al momento resultó la palomita [pene] de Adán y a ella también de repente le resultó el chuchito ${ }^{11}$. Entonces cuando llegó el Señor a buscarlos, ¿Adán?; Adán no habla, está escondido, ¿Eva? ¿Eva?... aquí estoy; ¿y qué estás haciendo?... tenemos vergüenza; ya los vistieron, bien tapaditos... ¿ ¿ve?, no me obedecieron lo que dije; yo te dije Eva que no comieras esta fruta pero por malcriada tus dedos se gastarán con la piedra de moler y la palma de la mano lo quemarás en el comal para levantar tortillas y tus hijos los parirás con dolor y vos Adán tendrás que trabajar y también tus hijos, por malcriado...» (López García, 2003: 213).

${ }^{10}$ Eva y la serpiente parecen ser la misma entidad engańadora, embaucadora.

11 Igualmente, según refiere Villa Rojas, los mayas de Quintana Roo consideran que la anatomía completa surgió de la primera comida, la manzana, que comieron Adán y Eva: un pedazo de la manzana hizo el pene de Adán y otros pedazos hicieron los senos y la vagina de Eva. Ya transformados de esa manera los dos se pusieron a pensar sobre el uso posible de los nuevos órganos y al descubrirlo, «cayeron en pecado» (1978: 438). 
En las narrativas de la educación moral y en los mitos que hemos visto, la apertura del corazón y de la vagina se identifica con el pecado, haciéndose responsable dicha apertura de provocar ciertas desgracias como, por ejemplo, la necesidad de trabajar, la obligación de comer, el sentimiento de vergüenza ante la desnudez o, en general, el advenimiento del sufrimiento.

Podríamos encontrar un diálogo productivo en el plano moral entre los mitos que hablan de estas mujeres agresivas y los huehuetlatolli. Como han sugerido algunos antropólogos del área maya, entidades como la Ciguanaba serían, en cierto modo, controladoras del orden moral: los hombres que acercándose a ella evidencian ciertos gustos por la transgresión sexual acabarían enloquecidos o castrados (Wisdom, 1961: 459).

De alguna forma, volviendo a los huehuetlatolli, se puede decir que el énfasis pedagógico en torno al control corporal tiene el sentido de señalar la necesidad de domesticar el corazón y abortar sus pulsiones naturales: los ojos que se mueven contenidamente, los pies que caminan o saltan "con honestidad», los oídos que se cierran a palabras de la calles, las manos que se emplean sólo en la actividad doméstica, la vagina quieta y frugal... son indicios claros de que el corazón está controlado.

Lo mismo se puede decir de las ideologías en torno al aperturismo de las palabras. La palabra pública de las mujeres, en la retórica narrativa de los consejos, es reprobable. Una de las razones que se desprende de los relatos sería la disyunción social que provocaría la presencia pública de la voz femenina. Y junto a esto nuevamente un corolario más o menos latente sobre el miedo. Por eso se ha fundamentado una ideología que hace equivalentes no sólo haraganería y mal uso del corazón/vagina (para abrirse a otros), sino también haraganería y mal uso de la boca (para abrirse incorrectamente a través de chismes, mentiras u otro tipo de inconveniencias). Junto al temor a las palabras embaucadoras y "calientes» de las mujeres, se teme al chisme y a la mentira por sus efectos deletéreos. En la región ch’orti' de Guatemala una mujer chismosa es una mujer no doméstica, cimarrona y agresiva.

La conveniencia del silencio o de la contención de la palabra femenina se reproduce en muchos relatos míticos. Básicamente estos mitos advierten del peligro que supone, en primer lugar, hablar con muchos y, en segundo lugar, hablar mucho. Por ejemplo, en el área ch'orti' se habla de la utilidad del silencio de las mujeres para evitar la acción maléfica de un tipo de entidades extrañas llamadas 
genéricamente «comengente» ${ }^{12}$. Los «comegente» son metonimia de los extraños con los que no conviene que las mujeres se relacionen ni hablen. Hablar con otros, con extraños, es estar expuesta a ser comida por ellos. Resulta significativo decir que entre los ch'orti' la expresión «estar en silencio» tiene una doble acepción: por un lado es estar callado pero, por otro, significa abstinencia sexual ${ }^{13}$.

Del mismo modo hablar mucho se hace equivalente a hablar mal, y en el caso femenino implica ser chismosa y mentirosa. Para apoyar la conveniencia de la palabra antigua respecto al comedimiento de las palabras hay también mitos, por ejemplo en la región ch'orti' los que refieren que aquellas mujeres que así actuasen en mundo no "ganarían» la Gloria sino que su presencia sería eternamente estática en el otro mundo: moviendo sus lenguas en rostros hieráticos ${ }^{14}$.

Hablar con pocos y hablar poco es un imperativo moral y social sobre todo para las mujeres. Isabel Neila habla de una conexión que tendría sentido entre los indígenas mayas de Chiapas: la idea de "buen vivir» como vivir en silencio. En su reflexión al respecto, dialogada con Paoli (2003), entiende que los valores del «buen vivir» (armonía, generosidad, tolerancia, belleza, «fuerza del corazón») estarían relacionados con el comedimiento en el uso de las palabras; ese tipo de palabras construyen alianzas sólidas e imprimen armonía ${ }^{15}$.

Como base de la modelación social, la contención está presente en las palabras formales que buscan la convergencia sentimental ${ }^{16}$. En la declaración amorosa cakchiquel el varón expone sus valores a la mujer que quiere para esposa: ser trabajador, bueno y reconocer sentimientos «que aprisionan su alma»:

«Vengo a ti ¿y tú no me quieres? ¿y por qué no me quieres? ¿qué es lo que yo he hecho? ¿acaso yo soy malo, esa es la razón por la que no me quieres? ¿acaso no soy hombre? ¿acaso no puedo trabajar yo? Yo soy bueno, si desprecias tu fortuna lo verás, después encontrarás otro peor que yo ¡ve que

12 Tras esta calificación genérica de «comegente» se encuentran algunas tipologías parcialmente diferenciadas: el Cadejo, los negros míticos y los húngaros (ver López García, 2001: 308-3011).

13 El mismo sentido tiene en determinados contextos «hablar»: en ciertas circunstancias si se dice «Fulanita está halando con tal hombre se entiende que está teniendo relaciones sexuales».

${ }_{14}$ Para profundizar en las consecuencias después de la muerte del mal uso de las palabras en el mundo, ver el análisis del ciclo mítico «Morir tres días» (en López García 2000 y 2003: 221-226).

15 Ver Neila 2014a.

16 Una amplia y sugerente reflexión sobre la conveniencia del silencio en el cortejo puede verse en Neila $2014^{\mathrm{a}}$. 
lo que te digo a ti es bueno, que si encuentras otro peor que yo, tu madre se acordará de mis palabras! Tengo lo que quieres ¿qué es lo que te hace falta? ¿acaso no vas a tener tu comida? ¿acaso no te voy a mantener yo? ¿acaso sólo te digo palabras bonitas? Yo tengo mi patrimonio ¿̨me ha faltado alguna vez? En mi casa te encontrarás bien. Buena gente es mi madre, es mi padre. Ellos no son malos. Si ellos te vieran mal yo te llevaría a tu hogar, mejor será que nos separemos, yo no quiero que te vean mal, porque en verdad te quiero, tú eres lo que busco, tú eres mi compañera, verdaderamente lo que tiene aprisionada mi alma. Mi corazón te ha hablado la verdad. Todo lo cierto que está en mi pecho, todo lo que está en mi alma...» (Stoll, 1958: 220).

En la respuesta de la muchacha está la presencia de la palabra antigua, tanto en su extensión como en su modulación y contenido: Vi utz a-ciux, ni takej ri a-tzij, ngui-c’ulé chavuech. Xa romá $x$-ch'oó vu chavé $x$-cho'o un c’ux chavé («Tu modo es bueno, acepto tus palabras, me caso contigo. Por eso te ha hablado mi alma, te ha hablado mi corazón» (ibíd.)

Si la mujer indígena usase otras palabras, curiosas, inquisitivas o sugestivas denotaría ese aperturismo que formalmente atemoriza a los hombres.

En definitiva, los relatos acerca la conveniencia de contener el corazón y las palabras femeninas confluyen en la idea de la utilidad práctica del significado: la exhortación tendría sentido porque así, según una exégesis primaria, se consigue seguridad de las mujeres y, en otra más profunda, se evita la posibilidad de castración o de enloquecimiento de los varones. El imperativo moral sería la excusa de la utilidad política que para los hombres tendría la contención femenina.

\section{Realidades inversas sobre libertad en la palabra y en el corazón}

Se podría esperar que la práctica social se siguiese de esos imperativos morales que se movilizan por intereses políticos. Pero como tantas veces esto no es así.

A pesar de los múltiples relatos etnográficos que parecen dar congruencia y continuidad histórica a aquellas exhortaciones morales que destacaron los cronistas respecto al peligro de la calle, lugar de la tentación de palabras y corazón, y a la necesidad de contener tanto uno como otras, tenemos otras muchas evidencias 
etnográficas que pueden llevar al desconcierto y cuestionar la contundencia y valor real de estas restricciones.

No solo la etnografía regional del último siglo, sino también las conclusiones recientes de ese campo de investigación que podríamos llamar arqueología y etnohistoria «de género» refieren la presencia pública de la mujer indígena durante la época prehispánica ${ }^{17}$.

El padre de Susan Tax, el también antropólogo Sol Tax, que había trabajado 40 años antes que su hija en otra comunidad maya, en este caso de cakchiqueles en el pueblo guatemalteco de Panajachel, no aprecia la existencia de un imperativo moral ineludible que llevase a la reclusión femenina en el hogar. De hecho los estudios exhaustivos de Sol Tax en esa comunidad desdicen en buena medida esta consideración. En los rubros que toma en consideración respecto a los usos sociales del tiempo no hay prácticamente diferencias entre hombres y mujeres. Concretamente los tiempos que ambos dedican a «Celebraciones de fiestas», "Visitas informales, chismografía y bebidas en ocasiones no especiales», «Visitas formales y entregas de regalos», «disputas, peleas, tiempo pasado en los juzgados, en prisión o preocupándose» $\mathrm{y}$ «Negocios», son prácticamente similares (1964: 219). Ciertamente anotaba que el 51\% del tiempo de trabajo femenino se emplea en tareas domésticas, pero hay muchas ocasiones y situaciones en las que la mujer gasta su tiempo fuera de lo que son tareas estrictamente de «dentro de la casa»: las mujeres cosechan, van solas con frecuencia a cortar hojas o mazorcas tiernas, contribuyen también a almacenar el maíz en la casa, realizan labores hortícolas y se encargan preferentemente de las tareas relacionadas con el corte y preparación del café. Además son las responsables de atender a los animales domésticos, muchos de los cuales se llevan lejos del patio.

Pero sobre todo considera Sol Tax que las mujeres salen mucho a la calle. Salen a vender casa por casa y «la cuarta parte de las mujeres y muchachas adultas

${ }^{17}$ Hay suficientes estudios históricos que hablan de la presencia femenina en el espacio público. Como refiere June Nash, las mujeres mexicas prehispánicas eran activas productoras y vendedoras (2001: 202). Destaca cómo el Códice Florentino las muestra vendiendo en el mercado como una parcela más de su actividad social en la que, además, habría que añadir otras ocupaciones que también aparecen en ese Códice: «curando a pacientes, cultivando plantas, oficiando en ritos religiosos y hasta cazando animales pequeños» (ibíd.: 205) Muchas otras investigaciones sobre el papel de las mujeres mesoamericanas en la época prehispánica destacan asimismo la actividad y presencia de éstas en la calle. Ver, por ejemplo, Joyce (2000), Ardren (2002) Rodríguez-Shadow (2000 y 2007), López Hernández (2011). 
van a vender a las casas y a los caminos. Todas las familias están representadas en el mercado por mujeres (1964: 327). La mayoría de ellas llega al mercado varias veces a la semana, durante una hora o dos en la mañana o en la tarde. Las mujeres dedican casi el doble del tiempo que los hombres al mercadeo: vendiendo en el mercado local, haciendo visitas a mercados foráneos, comprando en el mercado local, vendiendo en casas o comprando en tiendas.

Las chinautlecas de Guatemala van en masa al mercado de Guatemala. Cientos de ellas acuden cada jueves, viernes y sábados a los mercados de la ciudad de Guatemala llevando miles de cántaros. Consideran que vender allí es algo emocionante, aunque eso no quiere decir exactamente que se valore como placentero y divertido, pues resulta una experiencia agotadora y, de hecho, según afirma el antropólogo Rubén E. Reina sienten indiferencia por las reglas competitivas del mercado, lo que las preserva de la presión sicológica que seguramente resultaría de cualquier intento de conciliar los valores competitivos necesarios para operar en el mercado con aquellos necesarios para vivir en casa (1973: 115-116). Esto que sugiere Rubén E. Reina es especialmente interesante porque viene a decir que la oposición entre casa y calle en función del sexo no es plenamente significativa ni operativa y que, además, la actividad comercial no se subsume en su valor económico, sino que se trata de algo más amplio e importante.

La actuación femenina en el mercado, conociendo precios y sabiendo regatear, según Robert Redfield, «son virtudes que se inculcan a las jóvenes y son tan importantes para una mujer como saber hacer tortillas. Si una muchacha hace mal un negocio probablemente la gente se avergonzará de ella» (1956: 52).

Por otro lado la presencia femenina en el mercado da pie a tener cierta independencia económica a partir del dinero que se gana. En Chinautla una mujer que acumula y guarda independientemente el dinero que ha ganado con una venta no es irresponsable, sino justamente lo contrario. La independencia económica de la mujer se muestra cuando ella vende su propia alfarería en el mercado sin consultar con su marido, aun en aquellas raras ocasiones en que él está presente habiéndole ayudado a llevar las tinajas a la ciudad (1973: 308).

En la región ch'orti' las mujeres indígenas hablan sin problema de «su pisto», su dinero, aquel que obtienen de vender sus artesanías o animales que ellas han cuidado o el que obtienen de programas de cooperación orientados a ellas. Por regla general no debe rendir cuenta a su marido de lo que gana y en qué lo gasta, aunque es cierto que se espera que lo gaste en la familia. Según cuenta Wisdom 
respecto a la participación indígena en el mercado, en el pasado había cierta división por género en las actividades comerciales, "generalmente concurren juntos esposo y esposa de manera que mientras ella hace la mayor parte de las ventas, él compra los artículos que necesitan en la casa para el consumo de la siguiente semana. No obstante la regla general indica que cada sexo debe vender los artículos que produce, fabrica o utiliza. Por ello las mujeres venden jabón, petates, artículos de alfarería, recipientes de calabaza, copal, candelas, cigarros, todos los tintes excepto el de índigo, remedios femeninos, cacao, shepes, queso y mazorcas cocidas. Los varones venden maíz (sin cocer), frijol, frutas cultivadas, azúcar nativa, heno, leña, artículos de fibra tejida, remedios masculinos, sandalias, carbón vegetal, ocote, tinte de índigo, sombreros cosidos, escobas y utensilios de madera para uso doméstico. Por lo general las esposas se hacen acompañar de sus esposos o hijos en la plaza pues se considera impropio que vendan solas a menos que sean ancianas (1961: 231). Sería similar en otros contextos mayas, según Robert Redfield, la esposa puede vender huevos o aves de corral para su propio lucro y puede aprovechar cualquier situación sobrevenida para vender incluso en ámbitos que parecerían irreverentes: por ejemplo, en un hogar de Panajachel la hija de una unidad doméstica hacía dulces y los vendía a los miembros de una cofradía religiosa, al frente de la cual se hallaba su padre y lo hacía justamente afuera del cuarto de la casa de su familia, donde estaba colocado el altar y donde se ofrecían las oraciones (1952: 53).

Se podría pensar que la presencia pública de la mujer indígena en el mercado no lleva aparejado un desempeño público de la palabra, y que no es sino una extensión de la idea de hogar y de la necesidad de provisión de alimentos para la casa; también que la palabra se usa dentro de ese marco racional para comprar y vender, en definitiva, como expresión de laboriosidad. Pero no es esto lo que nos cuentan las etnografías regionales. Evidentemente mercadear mucho implica hablar mucho y no sólo ni necesariamente del acto de comercio que se está tratando: vendedoras y compradoras se cuentan noticias familiares y sociales, comparten conocimientos y emociones, bromean e intercambian sentimientos. Y además conciertan vínculos sociales: relaciones de compadrazgo, compromisos matrimoniales, invitaciones rituales...

En la región ch'orti' cuando una mujer baja al mercado de Jocotán todos los de la casa la esperan por las novedades que pueda traer, no sólo respecto a los productos que ha comprado sino también en forma de relatos de todo tipo que ha conseguido. 
Ruth Bunzel, la antropóloga que estudió con mayor profundidad el mercado indígena, concretamente el de Chichicastenango, dice que sin duda la actividad femenina en el mercado es más social que económica. Pone el ejemplo de una mujer en cuyo patio tiene un enredo donde crecen tres tomates: «...los cortará, pulirá y levantándose antes del alba, caminará 10 millas al mercado para venderlos. Allí estará sentada bajo el sol todo el día y finalmente los venderá; comprará luego con ese dinero tres tomates de la mujer de un puesto de venta cercano y en la noche caminará llevándolos 10 millas de regreso a su vivienda, con la sensación gratificante de haber realizado algo» (1981: 107). La cuestión central era para Bunzel responder a una pregunta: ¡si no se consiguen utilidades económicas, qué se obtiene de esas labores? Lo responde a continuación:

«...los indígenas quichés de Chichicastenango viven en celoso aislamiento en su propio terreno; en esa situación, el mercado es la respuesta a la necesidad de vida social. Aquí el joven inspecciona los prospectos matrimoniales y la muchacha tiene señalado su pretendiente y, en privado, toma la resolución» (ibíd.: 107).

Si se pregunta para qué acuden las mujeres al mercado la respuesta no puede ser simplemente a vender y comprar. Por lo menos tan importante como eso es decir que acuden a hablar, a entablar otros negocios, a aprender, a comer cosas diferentes, a conocer novedades y también a bromear y reír. El mercado sería el locus preferente donde la palabra curiosa femenina se expresa.

Lo mismo podemos decir respecto a la idea de que la enseñanza moral inculcada a las mujeres indígenas lleva aparejada la prisión del corazón y de las relaciones sexuales. De hecho libertad de las palabras y libertad de corazón están lógica y simbólicamente implicadas, como están lógica y simbólicamente implicada las admoniciones para la oclusión de boca y vagina. En el fondo esa "palabra antigua» («no seas curiosa con tus palabras», «no sigas tu corazón») se identificó por los cronistas con la restricción clara en la iniciativa amorosa y sexual.

En mi experiencia de campo he conocido múltiples casos no sólo de hombres que abandonan a sus esposas sino de esposas que abandonan a sus maridos y a sus hijos atraídas por un varón. Siempre me pareció desconcertante el énfasis que se pone en la región en torno a la idea de la mujer indígena como "guardiana» y presencia silenciosa del hogar que contrastaba con una realidad tan nítida de ausencia de la casa y de tránsitos familiares, afectivos y sexuales tan significativos. 
Uno de los casos más llamativos que he conocido últimamente es el de doña Felipa, una mujer ch'orti' de Tunucó de unos 45 años y durante muchos años esposa de don Isidro, carismático líder del grupo de familia extendida de los Roque. En 2010, tres años después de fallecer don Isidro, el caserío estaba integrado por seis unidades domésticas. En el epicentro estaba la casa de dońa Felipa en cuyo hogar permanecían los dos más pequeños de sus hijos; otros dos hijos, varón y hembra, habían formado sus hogares a pocos metros; las otras tres viviendas estaban ocupadas por familias de un hermano, una hermana y una cuñada de don Isidro, viuda esta última de otro hermano de don Isidro. En ese entorno dońa Felipa tenía cuatro hijos, cuatro nietos, tres cuñadas, dos cuñados, 12 sobrinos y 6 sobrinos nietos. En esa familia modélica doña Felipa cumplía ya en la madurez los papeles de la formalidad doméstica. No tenía ninguno de los problemas que se presentan habitualmente a mujeres viudas, era cuidada y mantenida por sus hijos y era querida y respetada por todos como extensión del respeto que mereció don Isidro, uno de los más reconocidos curanderos y el único Padrino de Invierno ${ }^{18}$ de la región. Cuando en el verano de 2011 tuve noticia de la fuga de dońa Felipa con su cuñado don Bernabé (hermano de don Isidro y vecino suyo) no daba crédito: salieron ambos «de escondidas» y se fueron llevándose apenas las ropas y cargando dońa Felipa sólo a la más pequeña de sus hijas. Las versiones que circulaban sobre el acontecimiento eran de todo tipo, aunque la crítica se conducía hacia la irresponsabilidad y no se refería en ningún caso a la inmoralidad...Todos querían encontrar razones de por qué se fue. Álvaro, su hijo mayor, me comentaba «no compriendo que sería que abandonó el hogar y dejó sus familias... qué fue a hallar allá ónde se fue de juída [huída]. Acá estaban sus familias, ella tenía suficiente maíz y suficiente frijol, acá en el puesto pasaba la vida sin problema...» Cuando fui a visitarla tenía ya en la vecina aldea de Potrero una pequeña casita en la cresta de la montaña desde donde se divisaba la quebrada Torjá y desde donde se podía intuir en la lejanía las viviendas de su antiguo caserío. Lo más llamativo para mí era el contraste entre esta casa aislada y solitaria y aquella agrupación extensa con tanta gente y siempre con el bullicio de niños pequeños, pavos, multitud de perros y multitud de visitas. Me comentó que extrañaba a su familia y que sentía pena porque sus hijos no le hablaban y sólo llegaba su hija Telma a visitarla. Me explicó algo parecido a que su marcha se debió a una llamada de su corazón y que no se la podía considerar irresponsable porque sus familias estaban criadas y sólo la pequeña, la Andreincha, todavía

${ }^{18}$ Los Padrinos de Invierno han sido los principales especialista rituales entre los ch'orti'. Su labor consiste en atraer la lluvia en momentos de persistente sequía. Ver López García 2010. 
no estaba criada y la había traído con ella ${ }^{19}$. Le pregunté si acaso no tenía allá en su caserío suficiente maíz; me dijo que sí, aunque dependía de los hijos y de los cuñados, que por eso era bueno tener un compañero varón para que trajese maíz sólo para una, ¿entonces se marchó para tener seguridad de tener maíz?, me respondió que por eso sí, pero también "porque siempre es bueno estar pegada a un varón». A lo largo de nuestra conversación me repitió dos o tres veces eso mismo: «siempre es bueno estar pegada a un varón», y al decirlo de ese modo y en ese contexto conversacional quedaba claro que ese deseo de «estar pegada» se relaciona con aspectos que tienen que ver con un tipo de compañía, con sentimientos y también con relaciones sexuales.

Desde luego responder a la llamada del corazón es algo inevitable hasta el punto de que no atenderla puede acarrear enfermedad. Es cierto en todo caso que una mujer puede acudir a "pegarse» con un varón sin que haya una llamada del corazón, simplemente porque tiene un interés material o porque persigue una venganza. El problema está en saber si el corazón está limpio o sucio y, por tanto, la llamada que hace es limpia o no. Las maneras de comprobarlo son variadas. Por ejemplo mirando el corazón de una tortilla de maíz se puede saber cómo es el corazón de la mujer que la ha hecho: si se encuentra alguna suciedad en el corazón de una tortilla es signo de la suciedad de la mujer que molió el maíz.

La apertura sentimental y sexual de la mujer indígena guatemalteca no ha sido infrecuente y en un repaso etnográfico impresionista podemos encontrar referencias más contundentes. Entre los mayas pokomanes de San Luis Jilotepeque, «el adulterio y la infidelidad son pasatiempos que se permiten muchos indígenas de ambos sexos. Aparentemente la mejor oportunidad se presenta cuando el jefe de la casa viaja a San Salvador para vender artículos de alfarería. En tales ocasiones, la esposa, que permanece en casa, con frecuencia encuentra la oportunidad para consolarse con los esposos o con los convivientes de otras mujeres» (Gillin, 1958: 161). Igual sucede en la población mam de Santiago Chimaltenango donde las relaciones extramaritales son frecuentes y la mayoría de los informantes varones del antropólogo Charles Wagley le hablaban de sus recientes aventuras extramaritales (1957: 164-165).

19 Según refiere Charles Wagley en Santiago Chimaltenango, salvo los niños de pecho lo normal es que los niños queden con el padre después del divorcio. Incluso los de pecho pueden ser reclamados después por el padre (166). 
En la región ixil el concubinato interétnico era frecuente en los años 40 del s. XX donde, según Lincoln, era evidente «el ansia de las mujeres indígenas por tener hijos con los ladinos y la forma despreocupada en que los ladinos tenían relaciones con las mujeres ixiles casadas al estar ausentes sus maridos» (1945: 78-79). Todavía en los años 70 Colby y Van den Berghe apuntaban que el concubinato interétnico e intraétnico era relativamente común (1977: 166).

Una nota más de la zona ch'orti donde ha habido y hay normas claras de comportamiento respecto a la interacción sentimental y sexual como hemos visto. Según Wisdom los adultos esperan que las muchachas mayores se muestren tímidas y reservadas como sus madres. Entre ellas hablan poco y en voz baja, incluso cuando están solas, y no dan muestras de excitación cuando se reúnen; al mismo tiempo la regla general dice que ha de practicarse una monogamia estricta. No obstante en Tunucó hay varios casos conocidos de hombres que tienen una concubina viviendo en la misma casa de las esposas y tienen hijos con ambas. La tenencia de concubinas por hombres casados es vista generalmente con malos ojos, especialmente cuando la relación no se mantiene al margen del conocimiento público. Casi todos los varones solteros y muchos de los casados tienen relaciones sexuales secretas con muchachas solteras que viven en hogares paternos, lo que parece ser considerado, lo mismo que la embriaguez, una debilidad más que un vicio (1961: 340-346). Setenta y cinco años después de esas referencias de Wisdom yo mismo he encontrado algo similar e incluso más notorio en la misma comunidad de Tunucó Abajo: a finales de los años 90 del s. XX conocía pocas parejas de más de 40 años que no hubiesen tenido otro compañero o compañera sentimental y sexual.

En el Santiago Chimaltenango de los años 50 del s. XX habría unos diez varones que tenían de manera abierta dos esposas. En los hogares poligínicos lo normal es que al cabo de algún tiempo la segunda esposa que tiene papeles de concubina se case con un hombre sin esposa que pueda garantizar una herencia para los hijos y acompañarlo durante los ritos (1957: 168-69). Pero la apertura del corazón en consonancia con la necesidad de compañía se aprecia sobre todo en Santiago Chimaltenango en el hecho de la rapidez con la que el viudo y la viuda encuentran nueva pareja: «una viuda joven o de edad mediana recibe ofertas matrimoniales poco tiempo después de que termine el periodo ritual de veinte días» (ibíd.).

Sin duda el dilema sobre cómo actuar ante la llamada del corazón es de los más fuertes que pueden presentarse, porque ciertamente se confronta a cam- 
biantes imperativos sociales y morales. Y no sólo por eso, sino porque a veces lo que parece una apertura limpia del corazón femenino en el fondo es el resultado de una acción hechiceril masculina. Seguramente los procedimientos mágicos más sofisticados en la región ch'orti' son los que se usan para orientar la senda del corazón en una dirección determinada, para vencer resistencias y conseguir también aperturas sexuales. Cuenta Wisdom cómo los curanderos ch'orti’s se valen de una mosca verde, la cantárida, para conseguir que una mujer consienta en tener relaciones sexuales: las alas de las moscas son arrancadas y cortadas en trocitos, se mezclan con aguardiente y las ingiere la mujer en un trago y «después de algunos minutos de haber bebido se muestra "dispuesta». Igualmente el pájaro llamado «siguamonte» es muy utilizado para inducir a una persona del sexo opuesto atener relaciones sexuales: los curanderos extraen el corazón del pájaro, lo hornean y lo muelen; este polvo se mezcla con la comida o bebida que vaya a consumir la persona deseada que pierde la voluntad (1961: 401-402).

En Santiago Chimaltenango igualmente son normales los actos mágicos para seducir y conservar a hombres y mujeres. Una estrategia exitosa es la de ingerir el cuerpo del otro para atraer; por ejemplo, cuenta Wagley cómo un hombre obsequió a una mujer recién casada la comida que había frotado sobre su pene y así la persuadió de que abandonara a su esposo y se fuera con él. Otra mujer, por su parte, impidió la ruptura matrimonial dándole a su marido tortillas que había mezclado con leche y sudor de su propio cuerpo (ibíd.: 165-166).

¿Son entonces los huehuetlatolli prehispánicos y coloniales, y todas sus secuelas, papel mojado, retórica simple? En apoyo de estas tesis que pone énfasis en la realidad se alían algunas valoraciones críticas relativas a la originalidad indígena de estos consejos y exhortaciones.

Según considera Baudot, Olmos en la Suma habría integrado no sólo parte de los huehuatloli recogidos entre sus informantes sino también las «adaptaciones» a la nueva fe; es decir, modificados en función de ésta: «pretendía ser una tentativa de proporcionar modelos, ejemplos y esquemas rectores a una futura sociedad concebida por los franciscanos»... La obra sería un breviario para ayudar a construir un México nuevo que intentase salvaguardar lo más posible la personalidad y por tanto la autenticidad del antiguo, pero integrado todo en la lógica del Antiguo Testamento (1983: 219).

Sin duda hay algo más que «adaptaciones» y algo más que aire de familia entre aquellas recomendaciones dirigidas a la mujer indígena con las que 
abríamos el texto con otras como, por ejemplo, las que refiere Luis Vives en la Instrucción de la mujer cristiana. Él, como tantos moralistas europeos anteriores, también focalizaron su atención en la contención de la libertad de movimientos del cuerpo y, por tanto, en la conveniencia de no sacar la boca, ni el corazón ni la vagina a pasear fuera de la casa. Unos breves fragmentos nos permiten reconocer las convergencias:

«Los santos escritores y maestros del humano vivir, dicen que la muerte entra (como por unas ventanas) en el alma por los sentidos, los cuales son solicitados y fatigados por los placeres y halagos del mundo, que con su cebo sabroso engañan a nuestra voluntad y tienenla como cautiva. Así que va mucho en que la mujer, o nunca salga de casa o muy tarde, cuanto más que sus negocios no deben ser tantos que ella haya de andar por parte donde su honestidad puede tropezar a cada paso» (1948: 69).

«La nuestra virgen holgarse ha de pasar el tiempo con las otras vírgenes de su igual, es a saber, con las que son en el semblante vergonzosas, en las palabras templadas, en el seso cuerdas, en la conversación honestas y en toda la vida recatadas y discretas... Cuando la virgen se viere sola, no esté sin hacer algo, porque pasa peligro la mujer en estar sola y ociosa. No se meta por el piélago de los pensamientos adelante, aunque en el principio sean honestos y buenos, porque el ánimo de la mujer es ligero y en pocas partes halla puerto seguro, tanto que a algunos ha parecido que Publio Siro tuvo razón en decir que la mujer que sola está pensando, en alguna maldad debe pensar» (ibíd.: 71).

«... antes de que saque el pie de la casa, apercíbase en su corazón cómo sale a la batalla del mundo. Piense qué es lo que verá, qué oirá, qué dirá, considere que a cada paso, como de trascantón, le saldrán cosas que le darán traspiés por hacerla tropezar y caer... sepa que sale a la vanidad de este mundo, de la cual se ha mucho de guardar que con su torbellino no la arrebate, teniendo siempre ojo a las cosas del cielo; en todo lo que viere debe imaginar en su pensamiento que es juego público de la vida humana de, cuyos vicios no solo no debe dejarse tocar, mas aún debe con mucho cuidado enmendar los suyos" (ibíd.: 93).

«Guárdese de salir tan compuesta, o andar tan requerida, o hacer o decir cosa que sea algún armadijo del demonio para entrampar almas, porque no solo ella debe pecar, mas aun dará ocasión de pecar... Saliendo la doncella 
fuera... no cure de mirar a nadie ni ser mirada, ni vuelva los ojos acá ni acullá, ni pregunte quién está en aquella casa o en esotra...no mire a los hombres por ver si ellos la miran; y si estuvieren mirando hacia donde ella estuviere con otras mujeres, no piense luego que lo hacen por ella, ni que hablan de sus lindos cabellos... nuestra doncella no debe estar muy ufana con su hermosura» (ibíd.: 93)

«... porque la risa es indicio o descubrimiento del ánimo liviano, guárdese de reír sueltamente ni cacarear (como dicen).... Ninguna debe reír a hombre que se le riere, pero no hay necesidad, como quiera que esto no lo hacen sino las desvergonzadas o locas.... No consienta ser pellizcada, ni tocada deshonestamente, y esto ni lo disimule callando, ni de voces como loca: múdese disimulando del lugar, o váyase si es menester (ibíd.: 96).

En fin, podríamos seguir con otros muchos párrafos que demostrarían aquella convergencia moral a la que se refería Torquemada en la educación de las mujeres indígenas y occidentales, y que nos llevarían a fundamentar con base a la experiencia la negación del valor social de la retórica.

\section{Retórica moral y cambio social}

Entonces, como me preguntaba más arriba ¿̨las exhortaciones, los consejos, son retórica simple? ¿Los cambios en la práctica social de las mujeres que estamos viendo desde hace décadas indican que la palabra antigua ha muerto?

Había dejado una páginas más atrás a doña Felipa en 2011 en su nueva casa de la cresta de Potrero con su nuevo compañero, su cuñado, don Bernabé. Hay que recalcar las circunstancia personales de doña Felipa: próxima a cumplir los cincuenta ańos, con cuatro nietos, con el prestigio de ser viuda de un carismático Padrino de Invierno, con unas relaciones de parentesco armónicas y placenteras, entre las que se incluía una muy buena relación son su cuñada Romelia, esposa de don Bernabé. Los consejos que habría recibido dona Felipa en su infancia acerca de la conveniencia de la cerrazón femenina habrían sido ignorados, y el imperativo moral vencido por el imperativo sentimental la movería finalmente en una u otra dirección... eso parecía de la historia «real» en 2011. Sin embargo sucedió como si las "palabras antiguas» resucitasen, en su caso, para su desgracia. 
En diciembre de 2013 volví a Tunucó. Pregunté a Telma por su madre, «tiene como seis meses que se falleció... y don Bernabé también tiene tres meses que murió», me dijo... Y cómo: «mi mamá se enfermó y en apenas una semana se falleció, mi tío don Bernabé fue baleado. Se había quedado solito en aquella casa donde se fue con mi mamá, se entraron en la noche y lo balearon...» El relato plano y asépticamente descriptivo de Telma lo fui complementando con otros: algunos no dudaban de que dońa Felipa fue brujeada y que algunos «corazones heridos» quisieron que don Bernabé regresase al hogar familiar después de haberlo despreciado. Murió doña Felipa pero don Bernabé siguió viviendo unas semanas sólo en aquella casita en la montańa, desafiando a las "palabras antiguas». Finalmente fue baleado una noche. Muchos dicen que lo mataron para robarle, pero no faltaron opiniones que hablaban de que «se había ganado su muerte», de que su actitud en los últimos meses, despreciando la familia aún cuando quedó solito, no era correcta. Uno de su sobrinos fue más allá: «si se hubiese regresado con su esposa y con sus hijos ahorita todavía estaría en el mundo" ¿había vencido finalmente la "palabra antigua»?

También dejé atrás a Eva en el mito ch'orti' con una moraleja contundente: su apertura sexual nos hizo pecadores y desgraciados, de manera que avisaba de los peligros de todas las aperturas sexuales femeninas. Pero en este caso es la narrativa quien ha sido domesticada por la acción ritual de los ch'orti's. Identificar el pecado y el mal de Eva con el surgimiento del sexo, el vestido, las palabras, y de la anatomía completa, ha incomodado a los ch'orti's.

En la finca donde vivían Adán y Eva permanecían sin comer, sin hablar, sin sexo y sin vestidos. A los ch'orti's les gusta comer, platicar, tener vestidos diferentes y practicar el sexo, con moderación. Por eso, sin renunciar a su catolicismo particular parecen empeñados en reinventar o reinterprepar su pasado mítico y en modificar el estilo de vida en la Gloria (que según la predicación católica que han entendido, será igual al Edén antes del pecado), empeño que pasa por convencer a Dios de su error al identificar pecado con comida, palabras, vestidos y sexo. Fundamentalmente tres estrategias refuerzan esa intención: ver y contar de diferente manera cómo es la Gloria cuando acuden allí (después de «morir tres días»), preparar a los muertos para una estancia en la Gloria diferente a la descrita en los mitos católicos y actuar soterradamente sobre las imágenes católicas.

En otro lugar (López García, 2000) he analizado la experiencia relativamente frecuente de algunos ch'orti's que «mueren tres días» y después «resucitan». En 
ese tiempo viajan conociendo la Gloria y el Infierno y se encargan de difundir cómo son. Seguramente el desencadenamiento de estas «muertes» vaya parejo al interés por modificar el estatus vital y emotivo de la Gloria. La Gloria que actualmente visitan los ch'orti's poco tiene que ver con ese lugar estático de contemplación defendido por el catolicismo oficial. Por el contrario, en la Gloria se come espléndidamente y verdadera comida, se bebe, se platica "cantadito» y se tienen buenos vestidos.

Las prácticas ritualizadas con los muertos reflejan igualmente el deseo de acudir a una Gloria afectiva. Los ch'orti's despiden a sus muertos y los reciben cada noviembre y cada cabo de año con sikines (espléndidas invitaciones culinarias) $y$, aunque en la actualidad los indígenas no reciben a los muertos en el sikín con ropa, sino sólo con comida, en el pasado dejaban junto al altar donde iban a llegar un traje nuevo, calzón y camisa o enaguas, según el sexo; mientras esto sucede la concurrencia los recibe con cantos ${ }^{20}$. Parecería como si se quisiese recrear la Gloria deseada en la tierra, para que el difunto no notase la diferencia: cantos, ropa limpia y nueva y los mejores alimentos le esperan. Por último, los muertos son despedidos con las palabras más gratas a los oídos ch'orti’s, «palabras calientes», es decir, palabras entonadas, cánticos que los aproximan desde el momento de la muerte a la Gloria porque allí, como cuentan los que han visitado el mundo de los muertos, son bonitos los sonidos que se oyen.

Pero no es sólo como consecuencia de procesos azarosos (como «morir tres días») o tras la contingencia de la muerte cómo los ch'orti's actúan para modificar el perfil emotivo de la Gloria, también toda una gama de pequeñas acciones con imágenes sagradas caminan en esa dirección. De este modo, aunque las imágenes de personajes sagrados, sobre todo santos (las llamadas «semejanzas» de los seres sobrenaturales que habitan en el Cielo), se hayan empecinado en mantener su boca cerrada, los ch'orti’s parecen empeñados en abrírsela. Igual empeńo muestran en vestir las imágenes sagradas. A pesar de que el Cristo crucificado en la iglesia de Jocotán se empeñe en manifestarse semidesnudo, ellos igualmente se empeñarán, en cada ocasión que se les presente, en vestirlo anudándole pañuelos al cuello, en el torso y en la cintura. Más claramente se aprecia con respecto al Niño Jesús en Navidad. El Niño que ocupa los altares en las aldeas indígenas tiene su camarín adornado preciosamente, floreado y la propia imagen ricamente vestida; en cambio, el Niño-Dios en el pueblo mestizo está desnudo, en un pobre pesebre y recostado (cfr. Girad, 1962: 298). Aunque las cruces católicas quieran

20 Cfr. Girard, 1962: 282. 
seguir desnudas ellos siguen «alimentándolas», pues se sahúman con copal y se riegan con chilate, y "vistiéndolas», adornadas con hojas de conte y aromatizadas. Del mismo modo que los santos, cuyas imágenes ya están vestidas, se sobrevisten para saturar de sentido la conveniencia de vivir vestido.

Contrariamente al caso de doña Felipa y don Bernabé, respecto al mito de Adán y Eva podríamos decir que el valor de la palabra antigua se desdibuja.

Tener estos dos casos nos advierten claramente tanto de la precaución que cabe tener para no matar prematuramente algunas bases morales digamos, tradicionales, como para despreciar todos los cantos de sirena esencialistas.

Seguramente uno de los dilemas más problemáticos a los que nos enfrentamos en el campo como antropólogos sea el de identificar la importancia y valor relativo de narrativa frente a lo que observamos. Y uno de los errores más claros y sostenidos a lo largo del tiempo ha sido, desde mi punto de vista, el de otorgar más valor a uno o a otro en función de modas disciplinares o de prejuicios y fascinaciones políticas. Tan importante es el relato como la acción social y lo habitual es que los cambios en ambos ámbitos vayan acompasadamente y conviviendo aún en contradicción. Las narrativas a favor de la contención femenina han convivido y han tenido sentido aun cuando la realidad nos enseñaba muchas situaciones de apertura femenina.

Sin embargo en los últimos años puede ser que estemos en un escenario diferente y quizá ante un cambio revolucionario: una modificación radical en la inspiración narrativa de la moral que eliminaría defenitivamente a aquella que estamos llamando "palabra antigua».

Ciertamente vemos cómo desde hace pocos años las mujeres indígenas empiezan a hablar con muchos y también mucho y eso como consecuencia de que están recibiendo unos consejos y unas exhortaciones muy distintas que entran en contradicción con aquellas tradicionales.

Junto a las salidas al mercado, la participación femenina en grupos de acción propiciados por iglesias o por Ong se ha convertido en otro importante desencadenante de la externalización de la palabra de mujeres indígenas. En la región ch'orti' eso se inició en los años setenta del s. XX como consecuencia de la intervención de la Acción Católica que generó la creación de grupos en distintas comunidades llamados "promoción femenina». En esos grupos 
además de enseñar formas de "promoción femenina» a partir de enseñanzas prototípicas de un modelo global, y en cierta forma neocolonial (costura, cocina, higiene...), se invitaba a las mujeres a la participación social como promotoras de salud, catequistas e, incluso, representantes políticas. Pero sobre todo la expresión de la apertura se produjo con la llegada de Ong a partir de los años 90 del s. XX.

Esa nueva forma de socialización a través de las capacitaciones de las Ong, junto a la que se fomenta en las escuelas y en los grupos religiosos femeninos está provocando el cambio radical que se puede intuir, un cambio revolucionario hacia una apertura que rompe con la tradición.

Isabel Neila ha estudiado intensamente el cambio radical que está implicando que las mujeres indígenas pasen del silencio a las "palabras bonitas», de hablar poco al toj jamal ye (ser demasiado abiertas) como expresión del «nuevo vivir» tzotzil $^{21}$. En esa nueva situación las mujeres indígenas, "ya perdieron el miedo, la pena, ya platican más, ya hablan más... ahora cuando pregunta algo su mamá contestan y ya están más abiertas. Contestan más fuerte y se juntan. Es como si fueran abejas. Cuando tocas a la abeja y te vienen a atacar... Ahora así es» (Neila 2014).

Según su análisis estamos ciertamente ante un tiempo nuevo. Un «nuevo vivir», ach' kuxlejal, en el que los consejos de los padres y de los ancianos serán sustituidos por nuevas narrativas que vienen de la escuela, de la televisión o de instituciones nuevas. Esa tendencia que parece augurar un cambio revolucionario está implícito en la idea de «nuevo vivir».

Es muy posible, en todo caso, que el pasado vuelva a resistirse a morir y que las nuevas narrativas, las nuevas palabras para mujeres indígenas ("palabras bonitas», "palabras políticas» o "palabras públicas») puedan convivir con cierta presencia de ese pasado que marca la palabra antigua. Conociendo los últimos siglos de vida indígena en los que tantas cosas nuevas se han integrado con naturalidad en ese afán aditivo tan característico al menos de los pueblos mayas, podemos pensar que también existe la posibilidad, una vez más, de convivencia entre las palabras bonitas y el silencio.

${ }^{21}$ Ver Neila 2014b. 


\section{Bibliografía}

Ardren, T. (2002). Ancient Maya Women. Walnut Creek: Altamira Press.

BÁEz-Jorge, F. (1990). «Las seductoras macabras (imágenes numinosas de la sexualidad femenina en Mesoamérica)». La Palabra y el Hombre: Revista de la Universidad Veracruzana, 73: 5-28.

- (2000). El oficio de las Diosas (Dialéctica de la religiosidad popular en los grupos indios de México). Xalapa: Biblioteca de la Universidad Veracruzana.

- (2008a). El lugar de la captura (simbolismo de la vagina telúrica en la cosmovisión mesoamericana), Gobierno del Estado de Veracruz, México.

- (2008b). «El simbolismo de la vagina: metáforas de la fertilidad, el nacimiento y la muerte en Mesoamérica». En Medina, A. Etnografía de los confines. Andanzas de Anne Chapman. México: Universidad Nacional Autónoma de México.

Baudot, G. (1983). Utopía e historia en México. Los primeros cronistas de la civilización mexicana (1520-1569). Madrid: Espasa-Calpe.

Bunzel, R. (1981). Chichicastenango. Guatemala: Seminario de Integración Social de Guatemala.

Chinchilla, O. (2010). «La vagina dentada: Una interpretación de la Estela 25 de Izapa y las guacamayas del Juego de Pelota de Copán». Estudios de Cultura Maya, 36.

Colby, B. y van del Berghe, P. (1977), Ixiles y ladinos. Guatemala: Seminario de Integración Social de Guatemala.

Correa, G. (1955). El espiritu del mal en Guatemala. New Orleáns: Middle American Research Institute, Tulane University,.

Galinier, J. (1984). «L'Homme Sans Pied: Métaphores de la Castration et Imaginaire en Mésoamérique». L'Homme 24 (2): 41-58.

García Elgueta, M. (1962) [1869]. «Descripción Geográfica del Departamento de Totonicapán», Guatemala Indigena, Vol. II, n.o 4, pp. 115-192.

García Quintana, J. (1974). Estudios de Cultura Nahualtl, Vol. XI.

Gillin, J. (1958). San Luis Jilotepeque. La seguridad del individuo y de la sociedad en la cultura de una comunidad guatemalteca de indigenas y ladinos. Guatemala: Seminario de Integración Social.

Girard, R. (1962). Los Mayas eternos. México: Libro México Editores.

Joyce, R. (2000). Gender and Power in Prehispanic Mesoamerica. Austin: University of Texas Press.

Las Casas, Fray B. (1566). Apologetica Historia Sumaria. Fundación del Libro Total (http://www.ellibrototal.com/) 
Lincoln, J. (1945). An ehnological study of the ixil Indians of the Guatemala highlands. Chicago: University of Chicago Press.

León Portilla, M. (1961). «Consejo de un padre náhuatl a su hija». América Indígena, Vol. XXI, N.o 4, pp. 339-343.

López GarCíA, J. (2000). «Morir tres días: maneras maya-chortís de conocer el estilo de Dios y el estilo de los hombres». Cuadernos Hispanoamericanos. No 597, pp. 33-41.

- (2001). «La metáfora culinaria en el sentido de la historia según los mayas-ch’orti' del oriente de Guatemala», en López García, J., Alimentación y Sociedad en Iberoamérica y España. Cinco etnografias de la comida y la cocina. Cáceres: Universidad de Extremadura.

- (2003). Simbolos en la comida indigena guatemalteca. Una etnografía de la culinaria maya-ch'orti'. Quito: Abya Yala.

- (2010). Kumix. La lluvia en la mitología y el ritual maya-ch'orti. Guatemala: Cholsamaj.

López Hernández, M. (2011). Mujeres y diosas aztecas. México: CACCIANI.

Lupo, A. (2002). «El vientre que nutre y devora: representaciones de la tierra en la cosmología de los huaves del Istmo de Tehuantepec». Anuario del Centro de Estudios Superiores de México y Centro América. <http://www.articlearchives.com/1076495-1.html>.

Mendieta, Fray J. (2012). Historia eclesiástica Indiana. Barcelona: Red Editorial.

Monaghan, J. (1995). The Covenants with Earth and Rain: Exchange, Sacrifice, and Revelation in Mixtec Society. Oklahoma: University of Oklahoma Press.

Motolonía, fray Toribio de Benavente. (1971). Memoriales o Libro de las cosas de la Nueva España y de los naturales de ella, edición de Edmundo O'Gorman. México: UNAM, Instituto de Investigaciones Históricas, (Serie de Historiadores y Cronistas de Indias, 2).

NAsch, J. (2001). «Dialéctica del género y proceso laboral en la América de la preconquista, la colonial y la contemporánea», en León Portilla, Gutiérrez Estévez, M. y Gossen, G. (compiladores). México: Fondo de Cultura Económica.

Neila, I. (2014a). «El lenguaje informal del amor: del silencio a las palabras bonitas». (Pendiente de publicación).

- (2014b). «Toj jamal ye: la apertura emocional en el nuevo vivir tzotzil». (Pendiente de publicación).

Pitarch, P. (2001). «El laberinto de la traducción: la Declaración Universal de Derechos Humanos en tzeltal», en Pitarch, P. y López García, J. Los derechos humanos en tierras mayas. Politica, representaciones y moralidad. Madrid: Sociedad Española de Estudios Mayas. 
Redfield, R. (1956). "Comerciantes primitivos en Guatemala», en Cultura Indígena de Guatemala. Ensayos de Antropología Social. Guatemala: Seminario de Integración Social Guatemalteca, pp. 43-59.

Rodríguez-Shadow, M. (2000). Mujer azteca. México: UAM.

Rodríguez-SHADOw, M (coord.). (2007). Las mujeres en Mesoamérica prehispánica. Toluca: UAEM.

Sahagún, Fray Bernardino. (2001). Historia General de las cosas de la Nueva España. Madrid: DASTIN.

Stoll, O. (1958 -1884), Etnografía de Guatemala. Guatemala: Seminario de Integración Social de Guatemalteca.

TAx, Sol. (1964). El capitalismo del centavo: una economía indígena de Guatemala. Guatemala: Seminario de Integración Social de Guatemala.

TAx, Susan. (1980). «Actividad de desplazamiento en Zinacantán», en Evon Z. Vogt Los Zinacanteco. México: Instituto Indigenista Nacional, pp. 396-411.

Wagley, Ch. (1957). Santiago Chimaltenango. Estudio antropológico-social de una comunidad indigena de Huehuetenango. Guatemala: Seminario de Integración Social de Guatemala.

Willis, L. (2000). «Reflexiones desde mi experiencia de mujer». En McCleod, M. y CABrera, M. L., Identidad: rostros sin máscara (reflexiones sobre cosmovisión, género y etnicidad). Guatemala: Oxfam.

Wisdom, Ch. (1961). Los chortis de Guatemala. Guatemala: Seminario de Integración Social.

ZINGG, R. (1982). Los huicholes, una tribu de artistas. México: Instituto Nacional Indigenista. 